\title{
Literary Theory and Criticism: An Unaffordable Buzzword in English Literature?
}

\author{
Naushad Umarsharif Shaikh (Corresponding author) \\ Department of English and Translation, Faculty of Sciences and Arts Khulais, University of Jeddah, Khulais 21921, Jeddah, Saudi Arabia \\ E-mail: drnaushadumar@gmail.com
}

Received: 22-12-2015

Published: 01-05-2016
Accepted: 01-03-2016

doi:10.7575/aiac.ijalel.v.5n.3p.226
Advance Access Published: March 2016

URL: http://dx.doi.org/10.7575/aiac.ijalel.v.5n.3p.226

\begin{abstract}
The rise of literary theory has brought in stylistic obscurity and arguments full of theoretical discourses in literary studies with creative writing being read through the lens of critical theories rooted in such diverse disciplines as philosophy, psychology, economics and linguistics causing the twin effects of a broadening of critical approaches as well as a hiatus between literary texts and theoretical perspectives so much so that some scholars like Dave Ellis and Martin Ellis have come to question the very validity of theory-informed critiques of literature. Critics are fascinated by new theories, each time they emerged breaking the shell of the former one. Failing to convince both sides, theory always faced opposition. What makes critical theory an inevitable constituent of sophisticated courses in social disciplines is the fact about language that meaning cannot be usual or fixed. Moreover, language is subject to change when received at different ends it can be received with alterations making literary interpretations far from the objective results. This article discusses how theory changed the world of literature. Further, it establishes an argument; is literary theory necessary? Or have theories become unaffordable brands in literary studies?
\end{abstract}

Keywords: literary theory; literary criticism; English literature; validity of literary theories; literary interpretations

\section{Introduction}

Today, literary-critical theory has become an essential component of literary studies. The courses in such disciplines as arts, humanities and social sciences, have been altered to a considerable extent under the influence of critical theory. Despite the dominance of theory in literature, there remain, still, many vexing questions regarding the nature, significance and role of theoretical paradigms. Theory by no means is a unitary, coherent body of ideas impinging on literature. What is true about critical theory is that it has conked at the limitations between various disciplines. The other prominent and permanent feature of the critical theory has been that it has failed to provide a clear set of distinct conventions and comprehension which can simply be achieved in the process of making sense of a literary text. Yet, critical theory offers a comprehensive and extensive critique of issues across the table the readers face in the modernday world.

Moreover, Critical theory seems to be advantageous to those interested in culture as it affords them insights into the knowledge-power dynamics at work in literary discourse. In other words, literary theory has encouraged the idea that literature is cultural production. Yet, literary studies at present are under debates to the extent that the relationship between theory and literature is at a time questioned? Literary and critical theory transformed studies in the arts and humanities, introducing new paradigms for understanding cultural texts and new methods of interpretation. To define it in most widely accepted way; according to Oxford dictionary online, 'Critical theory is a philosophical approach to culture, and especially to literature, that seeks to confront the social, historical, and ideological forces and structures that produce and constrain it. The term is applied particularly to the work of the Frankfurt School' (Oxford Dictionary online, 2013).

\section{History of Critical Theory \\ 2.1 Critical Theory}

The German philosopher, Horkheimer defined Critical theory in his essay 'Traditional and Critical Theory' published in 1937, as social theory that aims at critiquing and changing the society than understanding or explaining. To Horkheimer, critical theory was radical and liberal form of Marxian theory having logical positivism whereas Hegel's understanding of the world is the base of Critical Theory as he construed in Phenomenology of the spirit1970 [1807]). According to him, the human world unfolds the treasure of knowledge used as base in the development of society. He further adds that the history of development of social differentiation, language and science have caused to set the boundaries for theory (1807: XXXI, 389, 451). Individual knowledge and action are inspired from the society itself and the inventions were nothing but result of developed thoughts and practices (1807: XLII, 16).To Hegel contradiction was a synthesis of two antagonistic elements. These contradictions were the driving factors of the history of society and ideas as negation is determining factor. For Hegel Theory and practice developed from the simple to the more complex and synthetic, whereas theory remained within the limitations of practice because it was only a reflection. Hegel asserts 
that theory and practice, in that point of time, had reached to such a stage that knowledge of the entire history of society and of ideas had become possible (1807: 12, 754).He could evaluate the history of human society and the history of knowledge as a series of contradictions. The resolution, Aufhebung: that is dialectic thinking in which one side recognized that both sides of the contradiction depended on each other and formed an identity (1807: 10) leading to a new level of knowledge- or a new standpoint on the world - that again comprised a defining contradiction.

It seems that Marx followed Hegel but differed on the question of theory and practice. He claimed that the real society did not have be the best society, not even the society that was best under the given historical circumstances. This is why Marx called his version of Hegel's dialectic a critical theory (Marx 1953[1867]: 22). He demanded "to topple all conditions, under which the human being is a humiliated, an enslaved, a lonely and a despised being" (Marx 1976 [1845]: 385; trans.)This alteration of Hegel's theory of society and practice came as critical theory to the world. Though they differed on the concept of best society, they agreed on the notion that the human being was determined by society and its history (Adorno 1996: 261).

In the early half of the twentieth century, Hegel's and Marx's progressive approach towards the development of history and knowledge were questioned. Their theoretical assertions were confronted with a reality which happened to lead towards apocalypse than the best society. Adorno was not convinced by Marx's concept of future better life, but to him Hegel had chosen the clear answer that the existing society was the best society. But Adorno did not fully agree with this optimistic approach toward the present or future. In a theory he termed this concept Negative Dialectic (Negative Dialektik, 1975). It is at variance from Hegel's dialectic in its negative relation to the social totality (Adorno 1979 [1951]: 57). Adorno argued that this totality comprised elements that pointed beyond it. He called these elements "nonidentical". Thinking in a non-identical manner means, for Adorno, to start any analysis with the totality to show that each happening is determined by the totality. He asserted that there was more to reality than the contradictions presented by Hegel and Marx.

In short, being a school of thought, Critical theory focuses on the reflective reading of social and cultural assessment using the social sciences and the humanities as source of its knowledge. Critical theory, as a concept and a term has been looked in two different perspectives; the one having its sources in sociology and the latter that exists in literary criticism eventually described as a theory originated from the critique. According to the Germen theorist Max Horkheimer the ultimate aim of any critical theory is 'to liberate human beings from the circumstances that enslave them' (Horkheimer 1982, 244).

Considering the origin and the way it was brought up, the concept of critical theory represents the idea and philosophy of neo-Marxism that flourished in Germany in the beginning of the twentieth century. The nurturing school, the Frankfurt, depicted the methods of Karl Marx and the famous Austrian neurologist turned, Psychoanalyst, Sigmund Freud.

While developing Critical theory was acknowledged and had been associated to the Frankfurt School theoreticians like Herbert Marcuse, Theodor Adorno, Max Horkheimer, Walter Benjamin, and Erich Fromm, who set up critical theory as a school of thought. However, Modern critical theory has also been influenced by the latter group of Frankfurt School scholars like Jürgen Habermas, György Lukács, and Antonio Gramsci. According to Habermas, critical theory bears the roots in German idealism and extends to American pragmatism.

It is very evident in itself that theory like Literary or critical theories, when studied, its origin and sources of development has been getting in shape for centuries together having its traces in Greek etymology, are not exceptions to this rule. Socrates, Plato, Aristotle, had their own philosophy and ways to look at the things, a set of approach which can be called theory in good old days itself.

"Clearly, in the first instance, a theory must attempt to explain something. Its proponents may believe that it does this successfully but others may not. Jonathan Culler, an eminent populariser of literary theory, has made a useful distinction: '...to count as a theory, not only must an explanation not be obvious; it should involve a certain complexity"' (Culler, 1997).

The sense that Literary theory makes among the readers and critics today is that it is the study of various ways to sense the literary works. So far there are five main approaches to literature used as interpreting tools

Literary theory is the study of the principles which inform how critics make sense of literary works. There are ways of, or approaches to interpreting literature; realistic, historical, pragmatic, structural or canonical approaches. What is peculiar about all these approaches is that they are not reciprocally exclusive and most of the time they do overlap one another.

\subsection{Critical Theory and Its Importance}

Theoretical writing takes on inquiries, notions and issues that are associated with our encounter and with culture and society and our individual practices, and focuses precisely on the literary, artistic behavior and interactions in our world. Critical theory challenges the human interactions and behavior with the material world. In brief, critical theory targets to promote analysis and reading of cultural and social human experiences which are self-reflexive in nature. It enables us to find and analyze cultural outcomes and communications with slightest differences in the meanings. On the contrary, Critical theory, ideology is also looked at as the dead end to human freedom.

Today, it is not that easy to avoid the term theory in general and Critical theory in particular as it has established itself as necessary element of developed and advanced course in the various disciplines like arts and in humanities including 
social sciences. The reliability of a language as the mode of communication is at stake and this is what gave rise to the wide acceptance of critical theory in literary criticism. Being essence and core of culture, Language is open to criticism and subject to change. Meaning of any piece of art struggles to settle between good and evil politically motivated forces and limitation of knowledge sometimes.

Critical theory questions and cross-examines the very common and legitimate meanings or claims on experiences, knowledge and facts.

\subsection{Critical Theory and Functions}

When we read books in order to understand the different literary theories or critical theories it is evident that we encounter queries on the very necessity of learning these tiresome theories.

These are the most probable questions faced by learners and readers of critical theories or probably highly obscurely simplified books on it by big theoretical writers in the field. Pick up any book on critical or literary theories you will find the issues rather made complicated by adding examples and references which are beyond learners understanding of the subject. What takes their soul out while reading such texts is the terms and phrases which they are not familiar with, It is even observed that the learners of English literature find reading abstract rhetorical statements difficult to understand.

By now, it is a well-established fact that the knowledge of critical theory has turned into a fashion for students and professors alike. In fact it is not less than a status symbol in the world of literature and literary theories, an unaffordable brand for commons in the field. We come across many, who keep their theoretical lingoes flaunting more to impress and less to comprehend.

The phrases or terms like Fractured Subjectivities, grammatology, trace arche-writing, hauntology, prosthesis of origin, "the stream of consciousness" and "the death of the author" will certainly sense little to the new learners unless they are used with proper referents attached to them. As a student I have happened to attend many lectures on literary theory, criticism by eminent scholars who failed to avoid the temptation of using such terms quite often to impress.

\subsection{Positive aspects of Critical theories}

Literary theory is a good aid indeed only when it serves the purpose of reading or brings good reading to the readers. Apart from inconvenience and complications, no doubt, there are some benefits trickled to the learners from an understanding of critical theory. It offers us a vision to experience our world differently by promoting the skills like self-evaluation, introspections and adding skills to experience the world around us in new dimensions. It brings complete change to the way we school our children: how we face our daily life and the entertaining elements like; television, news etc. our role as a voters and consumers; it does affect our reaction to negative opinions when we agree with others and when we don't. Further, it also affects on our ways of expressing our feelings and fears.

Critical theory has proved to be helpful in guiding or showing us the ways to reach our targets in our private as well as professional life, it improves our ability towards logical, creative thinking. In short, it helps us develop our insight towards the world and our experiences in it.

As has been rightly remarked by some theorists, Critical theory has had a significant impact on the business of literary criticism as it attempts to show the world through the lens of that theory, It is more or a less a scan that let you meet the results on your selective area of choice, like; psychological, economical, social, biographical, modern, postmodern etc. aspects of the literature. It develops the skills of selections, that is, how do you want a particular work of art to be read.

Critical theory enhance our ability to appreciate the literature by offering us different experiences various forms of the same. As a result, we realize that, after applying theories we get our experience in literature and capacity to understand theory enriched. It makes us think broadly and deeply about the world around us.

\section{Literature and Literary Theories}

\subsection{An Introduction to Literary Criticism and Theory}

Almost the whole Western world witnessed the emergence of Critical approaches as discipline in art, music and literature etc. in the $19^{\text {th }}$ century. A Hungarian literary historian, philosopher, aesthetician and critic George Lukas, a Marxist philosopher of German origin, who is profoundly influenced by Georg Wilhelm Friedrich Hegel and Karl Marx, Earnest Bloch, and a German literary critic and philosopher, Walter Benjamin started using Marxist theory to different subjects and courses of the arts. Ernest Jones, a Freudian began applying psychoanalytic theory to study culture, whereas Herbert Read, an English anarchist, poet and critic deployed Jungian theory (Analytical psychology originated from Swiss psychiatrist Cal Jung) Critical theory was accepted like fashion and different schools of critical theory were inclined to use foremost hypothetical discourses of the time to debate, evaluate, interpret, read and review the arts by the 1950s.In the 1960s, approaches like Capitalism, radicalism, psychoanalysis, and semiotics were incorporated in the emerging disciplines like film and media theory.

\subsection{Literary Criticism and Literary Theory}

Towards the end of twentieth century, literature and humanities departments in the European and American universities' welcomed 'theories' borrowed from the different disciplines of social and natural social and natural sciences. The rise of literary theories during the middle part of this century gained popularity as they grasped number of social and cultural factors including the development of post-structural philosophy, psychoanalysis, Marxism and social and cultural theories of scholars from all over the world. Apropos literary criticism and literary theory there are quite a lengthy 
debates it is difficult to subsume one under another. However, some conclusion can be drawn on the basis of the way they are treated, here are some;

According to Roger Fouler (2006), insisted that critical theory should be "Critical theory too should be separated from criticism, for it focuses on the reading of notions than works. It can be called an activity involving logic underlying criticism but individual and different.

As per the Culler's reading, literary theory can be explained as a mechanism that studies the nature of literature and consists the full account of the approaches of reading literature. But it started considering rational history, ethical philosophy, social insights and themes from various other interdisciplinaries concerning and interpreting meaning (Culler 1997, p.1). Literary theory, broadly speaking, literary theory is a lens through which a discerning reader can attend to the semantic richness and multifacetedness of literature. For instance, the psychological aspects and features of a literary text will be best interpreted and analyzed by a psychoanalytic theorist in the frame of psychoanalysis and psychology. Quite naturally, this theory will focus on psychological dimensions. However, traditional literary criticism has a propensity to focus on any specific aspect of a literary text. It is in the very nature of literary theory to center on selected aspects covered by it.

M.H. Abrams (2006) claims that Literary criticism refers to making general statements about the category of literature and making sense of the specific examples of that category. It is based on the critical theory or literary theory as they try to enlighten the suppositions and principles they contain. Literary criticism is not different than interpretation, in fact literary criticism nothing but applying critical theory to any work of art. To be precise, literary criticism is the product, critique generated after the application of critical theory on a particular literary work. Critic under the literary criticism questions the worth and class of a literary text. It tries to reach to a critical reading of what literary text wants to say in reference to its aesthetic, social, political and cultural statements. It is an act of evaluation of the worth, quality of a piece of literature. Literary criticism is an instrument that critics use for interpretation or understanding of the particular meanings of literary texts. Apart from discussing or evaluating the worth of a literary work; a literary critic tries to fathom the philosophical aspects and the very rationality by reading it on cultural and ideological basis that generates the other potential meaning than author intends to mean. In general, 'Literary theory', however, is set of developed system with a particular structure of literary criticism that involves academic, scientific or logical techniques aiming to read literary texts.

Michael Groden in his book, Johns Hopkins Guide to Literary Theory and Criticism (2004) treats literary criticism and literary theory as one and the same notions while describing the concepts. Whereas some critics characterizes literary criticism as an application published in text form. The literary critics belonging to academics are mostly form literature departments and they publish their readings in academic journals. But scholars from both the groups do not buy this ideas of literary theory is different from literary criticism.

\subsection{Functions of Literary Theory}

There are many heated discussion on efficacy of literary theories and its applications in day-to-day life. Though it is not directly related to everyone's life, literary theories have come up with some skills which are no doubt if used and applied as skills can result into trapping and targeting aims and achievements in more skilled and proficient ways. For instance Derrida's theory has its impact on not only individuals, political movements but across the various western and European philosophies. His theories were applied to support the crucial arguments and debates across the disciplines.

Literary theories offer an ability to read and see the work in multiple perspectives, the various facets of the value and limitations of the work of art. Each theory is a set of tests that a work of art is put under in order to reach a fuller understanding. Literary theories bring us to the results different from common personal views and interpretations, as theories are based on assumptions, they lead our assumptions to a well-designed way of each theory, which otherwise is not easy or possible to arrive at.

\subsection{Theory and Its Problems}

Right from Socrates and Plato to the Jonathan Culler and Terry Eagleton, at some point in their arguments on literary theories and philosophy or in an attempt to explain the widely misunderstood theories do confess that theories in general and literary theory in particular are at least not every one's cup of tea. To new learners, critical theory can appear obscure. To be honest, teachers may sometime find it notoriously hard to understand. Literary theories do challenge one's appetite to understand logic, implicit language and historical background required to reach to the next line or paragraph while reading the literary theories. In the simplest words 'theory is one's perspective to look at the particular work of piece but it does not get into one's head that simply. It is equally difficult to understand the areas that literary theory encompasses as the world to a child. Though it is widely discussed and well argued in work of writers on theory including Jonathan Culler and Terry Eagleton that theory encompasses reviews ideas and issues to our worldly encounters with culture and society. It is not that easy to any ordinary reader to figure out the outline of critical theory as it is routed deep in the abstract notions like cultural production and meanings. By challenging the very sense of understanding the artifacts from art, history and culture and stimulates us to reconsider our beliefs and understanding of the world and individuals around us.

In other words, critical theory targets to introspecting and analyzing one's experiences. It challenges the very tradition of our stereotypical patterns towards understanding individuals, cultures and our world around us. Today it has been categorically accepted in the disciplines across because of its widely acknowledged. 
Meaning is in elusive and abstruse phenomenon realized in different disciplines differently. For most of the theorist and writers on theory have agreed to the fact that language is not an authentic instrument to pass or convey the ideas in its true sense. There are many other dominant elements that language carries with it that contributes to change the meanings till it reaches to the reader (listener).

Theories do help in understanding the DNA of communication that makes world move. It gives an access to question our day to day interactions with others in our friends, colleagues and with the people we come across in our workday existence. By applying approaches we can make our culture, beliefs and people around open as they are often ambiguous and not easily accessed. One discipline takes the help of other disciplines like literary theories consult and borrow ideas from philosophy, linguistics, psychology, history, sociology and so on. Theory is significant and central as it redraws and opens the boundaries of other disciplines to redraft new potential approaches of enquiry. Therefore theory becomes an essential knowledge for the community belonging to the field of humanities and social sciences.

The interdependency and interdisciplinarity is one of important features of literary theories; for example, The Marxist concept of the socioeconomic considerations includes the psychological domain of human experience. To be very specific, Marxism, when, talks about the human psychology it does focus how socioeconomic factors affect them. Feminism is also not exceptional to this feature of interdisciplinarity, as it bears on psychoanalysis and Marxist concepts to reach the feminist concerns. This way by borrowing the ideas across the disciplines other than you study help you draw different views.

For a couple of decades studies and courses in literature in the universities of North America, Europe and some Asian countries, are surrounded by ascending interest in theoretical approaches called as Literary Theory. Its impact was so huge and effective that it brought the changes in the identities of the people in the field; those who follow and deal with approaches are known as 'Theory people' and others, preserving the culture and traditional values. Literary theory like; Formalism, Feminism deconstruction, structuralism and post structuralism, New Historicist, reader response criticism and feminist criticism, has influenced the culture and good number of disciplines in the academic world today. Theories proved to be ground-breaking, as it challenged the basic tenets like; what meaning is, what does an author do etc.

\section{How literary theories brought about enduring changes to literary criticism}

As was observed earlier in this article, applications of all the theories in literature are subject to change. Each new approach started pointing finger against the one before. These tendencies of theories of not compromising with the former one and framing its own set of rules to gain the self-identity proved to be major threat to the meaning of literary work and its stability among the changing cultural phenomenon which rendered instability, uncertainty and vagueness to meaning. As a result, to this uncertainty, Hamlet was read with new meaning each time and challenged the readers' ability to understand the piece of work and left them wandered and dissatisfied.

New criteria for achieving meanings were set, each time, a new theory came to its shape; Saussure's influential contribution asserted that the meaning of literary work is achieved by difference than 'presence'-a word bears meaning because of its difference from the words bearing meaning close to it. New theories began to exploit the status of words and their property of being ambiguous in nature. They started reaching to the meanings more than grammar could generate. It was believed that the words are full of meanings in excess, and they are accepted as polysemic in featuresirony is an example. Theories to survive and substantiate their stand, explored the complex nature of language other than the surface meanings. They started digging the cultural, linguistic and psychic aspects of the artifacts to reach to the meanings other than readers simply know. New literary formula and orders were set which came to challenge the 'truth' or reality of the meaning. There is not absolute meaning or truth as people generate the reality for the sake of culture, power and survival. The contemporary approaches emphasized that meaning is an internal world of any text than external; Roland Barthes claimed, etymologically, a text is a tissue made of former texts and language uses, hold historical references and practices containing 'play'. To him a text is a process and it is literary theory that can be applied to see the depth, complexity of that tissue. According to Derrida, culture and individuals are constructed through networks of connected language, symbol and discourse usages; he asserted that there is no 'outside-of-the-text', one cannot isolate a text from the constant circulation of meaning in the monetarist system of the culture; every text is connected and constituted through and of other texts.

Literature, in general, is a text of great significance and common readers read it out of their own depth of experience and life. There is no scale to measure the understanding of readers which, undoubtedly, differs from one another. Writers and authors need no other checks, as the case has been form the beginning itself, to make their work more effective, efficient and meaningful. Readers from time to time were the ultimate judges of the quality and meaning they retrieve out of reading. In fact, no reader went and asked author the meaning he wanted to convey. Today, literary theory has attacked this very essence of literary significance of the literature and literary study proving the approaches can only take the meaning of the grain. The functions of literature as a communication at the level of wisdom and a force behind the cultural lungs is endangered by theoretical interpretations which can narrow and group specific at a time. The very basic question remains unattained, if the interpretation is theory centred than the author whose intentions guide him to complete the work of art. The permanence and the consistency of the meaning is at stake if the forces of various approaches come to fix the meaning with the frame of rules governed by the contingent which can be and is subject to challenge and doubt by another theory. This is an attempt to challenge the humane culture, experiences and their ability to understand on the basis of social values. 
Today's pictures of the impact of literary theories go on to establish that English departments have shifted to the study of theory from the literary studies. Theory writers and critic have started treating literature as crime and investigation phenomenon. There are many rewriting of the canon took place in twentieth century, challenging the established status of literature as the cultural expression of life. Literature can never be treated as or compared to other sources of entertainment its meaning is as easy as free flow of the river. Treatment like detective or secret service attitude towards literature in all probability is unacceptable and should be avoided.

The issues, that has its origin in human world and its interaction with the materials around deserve and demands to be addressed and this is where the theory comes in to challenge the very established patterns of human interactions and its approach towards cultural and social activities. Theory by questioning the traditional assumptions can lead us to the productive understanding and enhanced cultural values.

\subsection{Literary theories in short}

To formalist critics, literature is a unique form that exhibits the human understanding and demands an examination on its own terms. It also propounds that factors required to understand the work are embedded in the work itself. Formalist critics are interested in style, construction, tone, imagery, etc. which are embedded in the text itself which collectively contribute to shape the text and cause effects on readers.

Biographical approach asserts that knowing author's life and his background can help readers to reach the meaning of the work. This approach centers on explaining the literary work by associating the text with the biography of the author.

Historical critics, who practice Historical Criticism pursues the social, cultural, and intellectual background to obtain the meaning of a literary work. They believe that the source behind any work is the historical background of an author. The focus of Gender Criticism focuses and analyses the role of sexual identity which they think plays a vital role in the creation and reception of literary works. Feminist and the recent approach, 'masculinist' by Robert Bly are examples of Gender Criticism. The approach Psychological criticism considers the modern psychology and its influence upon literature in its reason behind the existence of text. This modern approach, Psychological criticism has affected the world of critics and critique to the extent that the terms like wish fulfillment, sexuality, the unconscious etc. became focal points to read the human behavior. This theory changed our concepts of human behavior and angles to look at human beings.

Sociological criticism analyses the cultural, economic and political aspects of literature that a text contains. This approach focuses on the association of artist and society as the cause behind the constitution of the work.

Marxist criticism is one of the influential types of sociological criticism which focuses on the commercial and political fundamentals of art. It believes that all art is political.

Mythological Criticism is a synthesis of anthropology, psychology, history and comparative religion. This literary approach analyses the persistent common patterns at the core of most literary works. The important notion of mythological criticism is to focus on traditional elements in the art manifested in the archetype, a figure, character, story, place or image which induces a profound collective response.

Whereas, Reader-Response Criticism believes that literature is not a work existing in printed text on pages but it is a something that appeals and interact with the minds of readers. It takes account of reader's reaction or what happens to reader's way of thinking and feeling while involved in the interpretation of the text. According this tenet, meaning does not necessarily exist in the text literary, they believe that meanings can be only be driven and drawn from the individual readings. As meaning can differ individual to individual, this theory also focuses on the way social cultural and religious set ups affecting readings, however there are limits to the possible meanings. According to the critic of Reader-Response criticism the text itself limits the possible interpretations.

Deconstructionist criticism does not believe in the traditional suppositions that the language represents reality accurately. Deconstructionist do not buy this traditional assumption and assumes that language as a fundamentally unstable and as literature is made up of words which can give different mental images for different people there cannot be fixed, single meaning. For example words 'fish' and tree' can generate different mental images for different people. Deconstructionists' objects or challenges to the concepts;

a. Authors create or control the meaning of their texts referred as 'authors' ownership,

b. The concept of language as an instrument to gain power, in the process of understanding some interpretations of literary work as truth.

\subsection{Charges against Literary Theory}

\subsubsection{Why theory is facing charges?}

The first theorists and critic were formalist; Plato and Aristotle. Today in the name of literature majority of departments of humanities, English and Literature practice literary theory. Not all but some literary scholars give importance to a method of interpretation and treat it as an ultimate value of literary theory. The very few debated the efficacy of dragging students in the theory practice in the name of literature study. The students studying literature often tested on ability as critics or they are expected to give good interpretations of the literature they study at the college or degree level. There exists almost invisible line between the critics and teachers of literature that learners while lectured can hardly differentiate their switching so closely intermingling the literary theory and literature is. 
Most students studying literature at the college level are, to some degree or another, trained not simply to be critics of literature but, moreover, to function as theorists of literature with the ability to offer interpretations of literary texts through several different theoretical perspectives.

The language of literary theory is so highly coded that students new to the field face it difficult and challenging. Comprehension of literary or theoretical critique demands patience and practice to understand the specialized terms and paragraphs comprising complex compositions that literary theorists use in their critique. The interpretations of literary works comprise of so complex and rhetorically framed sentences and paragraphs that most of the learners often end up focusing on theory and miss the core of literature. The vocabulary of literary criticism and literary theory is in itself exhausting.

Being rhetorical in nature literary arguments are densely filled with bombarding words and terminologies derived from the various disciplinaries. Being exposed to the unacquainted phrases and terms, learners on reading and re-reading find themselves confused as the sentence structures remain above their lingual appetite.

Jonathan Culler, in his book containing the basic information about theory introduces the term theory as something which people are tired of having heard of it too much;

"'Theory', we are told, has radically changed the nature of literary studies, but people who say this do not mean literary theory, the systematic account of the nature of literature and of the methods for analysing it. When people complain that there is too much theory in literary studies these days, they don't mean too much systematic reflection on the nature of literature or debate about the distinctive qualities of literary language, for example. Far from it. They have something else in view"' (Culler 1997,p.1).

These years witnessed the ascendency of literary theories but all these approaches continued to baffle the reader with their jargon-ridden language and far from perspicuous arguments. This obscurantism haunted literary theories to the extent that semantic opacity became a hallmark of the proponents of theory. These star thinkers often used the language of science in a painfully vague sense to talk about their so called big ideas straddling literature and literary criticism.

All through these years theorists developed the theories but they developed it more complicated by all the probabilities. It seems that Faucault, Deriddah, Roland Barthus, believed to express through the jargon of science more than the world of literary one. As if the evaluations of literature were seemed to be crossed with the taxonomic expressions of the basic sciences therefore literature as well as existence of theories began to get endangered at the hands of its sustainers itself.

The danger in approaching literature through a particular theoretical lens is this; a single approach cannot account for the richness and multifacetedness of creative writing. To put it metaphorically, the way the beauty of a rainbow lies in the simultaneous existence of multiple colors and not in the separated existence of them, it can be argued that a single perspective on literature would be illuminating but at the same time inherently reductive.

When are we going to arrive to the fact; that creativity and beauty is the product of an imitation of the reality. The joy of enjoying the art is in presenting exactly the way it exists not in serving the art in elements to readers to understand the chemistry of reading art and pleasure of literature.

The postmodern critical theories are not less than brands which common learners cannot afford (understand)It has become a status symbol in the seminars and print media to use new difficult words (other fails to understand) and to feel proud in wearing (talking about) Where are we leading the literature to?

The scholarly journal, Philosophy and Literature had run the contest from 1995 to 1998, the writing competition; The Bad Writing Contest was born in a quest to reach the bad writers and egregious writing. It received the plain awful and awkward, jargon clogged paragraphs under in the name of academic prose. The journal received passages having regrettable style. In the winning entries of the contest some significant literary scholars in the United States were spotted. A Professor of rhetoric and comparative literature at the University of California at Berkeley, Judith Butler, who had once bagged a Guggenheim Fellowship, honored as 'one of the ten smartest people on the planet' composed the sentence that attracted the first prize of the contest. Another prominent figure in the fashionable academic field, Homi K. Bhabha, significant scholar on postcolonial studies, wrote the sentence that bagged the second prize.

Following is the sentence by Professor Butler that appeared in his work 'Further Reflections on the Conversations of Our Time' published in Diacritics, a scholarly journal in 1997:

"The move from a structuralist account in which capital is understood to structure social relations in relatively homologous ways to a view of hegemony in which power relations are subject to repetition, convergence, and rearticulation brought the question of temporality into the thinking of structure, and marked a shift from a form of Althusserian theory that takes structural totalities as theoretical objects to one in which the insights into the contingent possibility of structure inaugurate a renewedconception of hegemony as bound up with the contingent sites and strategies of the rearticulation of power" (Buler, 1997)

The second prize winner sentence by Homi K. Bhabha, a Professor of English at University of Chicago, that appeared in the another scholarly journal, The Location of Culture published by Routledge in 1994;

"If, for a while, the ruse of desire is calculable for the uses of discipline soon the repetition of guilt, justification, pseudo-scientific theories, superstition, spurious authorities, and 
classifications can be seen as the desperate effort to "normalize" formally the disturbance of a discourse of splitting that violates the rational, enlightened claims of its enunciatory modality"(K.Bhabha, 1994) .

Obscurity, complications and confusion are the features of writing by most prosperous scholars, experts who have achieved the writing skilled in years to write list of such writers is long; Hegel, Heidegger, Derrida, John Stuart Mill, Fredric Jameson, Dave Roden and so on.

Language is a system comprising of spoken or written symbols which are conventional, by using these symbols human beings express themselves and perform out their social and cultural role. Language can express, communicate various simple and at a time complex expressions.

Most of the students during their school age and days of graduation are given to understand that language is a tool of communication. It serves one of the basic purposes of human being in communication in the form of exchange of thoughts, feelings and ideas. However, when well learned scholars starts writing sentences which tends to be just a murmuring or lip flattering it seems that they are determined to spoil the very function of language. Their sentences are neither informative nor expressive or performatory. It seems theory writer failed to establish the very basic function of the language while launching their brand.

Today theorists and writers on theory have seemed to lose the very idea of language and its role that brings all of us under a social group and enable us to participate in culture. The features of English literature as mirror of life have been complicated beyond comprehension by using theories. It is assumed that when we study literature we develop a more comprehensive (reading) of the society and the world and study of critical theory is an enterprise that makes it further productive.

\subsection{Effects of the Development of Literary Theories}

Literary theory as a part of growth and development, (Scholars think it) has started focusing Poststructuralism: a psychoanalytic theories, New Historicism and cultural Materialsm as a part of innovations. From individual characters they have been shifted to the themes like; gender, sexuality, race, lesbian and ethnicity.

"In the context of contemporary literary theory, however, the more telling recent shift has been to the development of 'Cultural Theory' as the umbrella term for the whole field of enquiry. Most of the significant it is important to note - on postmodernism, post-colonialism, gay, lesbian and queer theories, in particular - is always more than literary in orientation. Such theories promote a global reinterpretation and redeployment of all forms of discourse as part of a radical cultural politics, among which 'the literary' may be merely one more or less significant form of representation. The present volume recognizes this, but in turn and given its brief, it attempts to retain a literary focus within the broad and constantly mutating processes of cultural history" (Raman Selden, et all, 2005).

According to Brian Boyd (2006), in his article, Theory Is Dead--Like a Zombie, published in Philosophy and Literature, students are inducted into the mysteries of Theory, Theory has surely dead? There are Bad Writing Contest and the events like Sokal hoax happened under the very nose of scholars from world renowned universities. David Scott Kasten's Shakespeare After Theory (1999) asserted that we are following theory passionately because it is proved and accepted to be useful and productive than intellectually bankrupt. In the world of theories and journals scholars like Martin Ellis and others in general have come to pass a judgment that 'Theory Has Failed', or 'End of Theory' or 'Theory is dead'

There happened to be some effects of developments in contemporary theory over the last decades that; Critical theory, being the tool, serves our purpose of taking out of the piece of literature the assumptions about literary form and identity that the world of scholars feeds on. It reveals the tests of aesthetic, moral and social values on which judgment calls are taken and issues are discussed. Since, most of the part is the business of scholars and readers we might be forced to ask; if it is suitable to engage students by introducing them and exposing them these brain numbing issues at graduate level. Are we just, in asking them to study and debate on most abstruse and confounding theoretical stuff in which they are yet immature and not well grown as they are not developed to read the experiences of the life from such a scholarly point.

\section{Conclusion}

It would be indeed injustice with the theory studies to say 'Theory is no more' or 'End of theory' has arrived but at the same time the charges leveled against literary theory are of serious concern as it tries to unsuccessfully attack the fundamental factors of literature;

In the early and mid of 1990s, there was a wave of criticism against literary theory and its nature. John Phillips in his article, What is Literary Theory and do we need to study it? commented that one can follow the literature and understand it without any canonical areas of literary theory, from formalism to deconstruction, for Literary study has remained strong and identifiable in its own right for 150 years. He considered literary theory over and above the normal requirements of literary study and charged with superfluity therefore it needs to be regarded as a separate subject. Theory is expected to work as catalyst in the process of obtaining meaning but what happens is meaning become obscure and sometimes intentionless which is unprincipled saga.

This darkness, obscurity and, vagueness, dragged the theory under a hot debate and scholars openly started goading on it. Daniel T. O'Hara bitterly criticized the nature of theory calling it,' Revisionary Madness', Jonathan Crewe called 
theory as 'Uncritical Practice', To Hershel Parker theory looked like 'lost authority: Non-sense, Skewed Meanings, and Intentionless Meanings', and Richard Rorty concluding theory practice as 'Philosophy without Principles". Knapp and Micheales criticized theory negatively because they believed that theoretical accounts of intentions always go wrong.

The ascension of theory proved be 'a flash in the pan' as it did not promised the effective and acceptable possible meanings and seemed to attack literature by causing damage to its privilege of entertaining and self-meaningful aspects, the parodies like, "The French have no head for theory" cannot easily be thrown away. It is indeed impractical, as for Roland Barthes, 'new criticism failed to be new fertilizer failed to be realized.

This has been a common charge against literary theory that its emergence and ascendancy has come to eclipse the real object of literary studies; in English departments worldwide, today, scholars are spending a major portion of the semester discussing ideas and issues rooted in such diverse disciplines as psychology, economics, history etc. rather than focusing on the beauty of literary texts themselves. As a result many literary journals are publishing articles that only tangentially touch literature proper. For instance, today applying Marxist literary theory is bringing ideas in philosophy and economics to bear on literature; applying psychoanalysis is bringing ideas in psychology to bear on literature; applying post structuralism is bringing ideas in philosophy and linguistics to bear on literature; applying post modernism is bringing ideas in architecture, philosophy and history.

To conclude, literary theory, regardless of polemic differences on position and an aid to reading and each method or an approach having a set of rules as capital and its only asset. Being subordinate and secondary in nature, literary theory depends on the literature so as its future. Literary theory is of no use if literature is suppressed and brought to its end, people will take the help of literary theory only as long as literature exists and proves to be important for societies and individuals in those societies. History of all the theorists and theories end into benefitting and adding popularity to the critics and writers than the readers and to the society. Literary theories and criticism succeeded in confusing most of the readers than settling their comprehensions.

Therefore it's a moral obligation on theory writers to understand the pulse of readers in general and individuals in the societies towards literature to avoid young men dropping out in universities and being distracted when they try to follow the literary discipline. They rather missed the literary discipline. There are strong allegations which are substantiated quite often, that theory scholars and theory writers have tried to meddle with literature as well as theory by brining obscurity and vagueness. The charges against critic demands a grave consideration as there has been successful attempts to make theory a brand unaffordable. In fact, the task at hand is to settle these issues and make theory an easy road, an acceptable help to readers than the abstract world full of obscurity. The literary theories have more or less followed the footprints of the critical theory and if to test its implications by a German philosopher and the member of the 'Frankfurt School, Max Horkheimer's touchstone that theories have definite pragmatic aims; "to liberate human beings from the circumstances that enslave them" (Horkheimer 1982, 244), how far have the critics and their critique succeeded into this practical purpose behind the theories?

\section{References}

Adams, H. (1971). Critical theory since Plato. New York: Harcourt Brace Jovanovich.

Auerbach, E., \& Trask, W. R. (2003). Mimesis: The representation of reality in Western literature. Princeton, NJ: Princeton University Press.

Baldick, Chris. (1987). In Frankenstein's Shadow: Myth, Monstrosity, and Nineteenth- Century Writing. Oxford: Oxford University Press.

Barthes, R., \& Heath, S. (1977). Image, music, text. New York: Hill and Wang.

Bataille, G. (1973). Literature and evil. London: Calder and Boyars.

Bhabha, H. K. (1994). The location of culture. London: Routledge.

Belsey, C. (1980). Critical Practice, London: Methuen.

Bennett, A. ed. (1995). Readers and Reading. London: Longman.

Bennett, A.(2005). The Author. London: Routledge.

Bennett, T. (1979). Formalism and Marxism. London: Methuen.

Bergson, H., Brereton, C., \& Rothwell, F. (1911). Laughter: An essay on the meaning of the comic. New York: Macmillan.

Bhabha, H. K. (1994). The location of culture. London: Routledge.

Brooker, P., ed. (1992). Modernism/Postmodernism. London: Longman.

Burgass, C. (1999). Challenging theory: Discipline after deconstruction. Aldershot, England: Ashgate.

Burke, S. (1998). The Death and Return of the Author: Criticism and Subjectivity in Barthes, Foucault and Derrida. Edinburgh: Edinburgh University Press.

Burke, S., ed. (1995). Authorship: From Plato to the Postmodern: A Reader. Edinburgh: Edinburgh University Press.

Buse, P. and Andrew S., eds. (1999). Ghosts: Deconstruction, Psychoanalysis, History. Basingstoke: Macmillan. 
Butler, J. (1990). Gender Trouble: Feminism and the Subversion of Identity. London: Routledge.

Butler, J. P. (1997). Further Reflections on Conversations of Our Time. Diacritics, 27(1), 13-15.

Charles A. W. (1989). A Theory of Argumentation. Alabama. University of Alabama Press.

Culler, J. (1997). Literary Theory: A Very Short Introduction. Oxford: Oxford University Press.

Deleuze, G., Smith, D. W., \& Greco, M. A. (1997). Gilles Deleuze: Essays critical and clinical. Minneapolis:

University of Minnesota Press.

Delgado, R., and Jean S., (2001).Critical Race Theory: An Introduction. New York: New York University Press.

Derrida, J., \& SPIVAK, G. C. (1980). Of grammatology. Baltimore: Johns Hopkins University Press.

Eagleton, T. (1996). Literary Theory. Minneapolis, MN: University of Minnesota Press.

Eagleton, T. (1976). Marxism and Literary Criticism. London: Routledge.

Eagleton, T. (1996). Literary Theory: An Introduction, 2nd edn. Oxford: Basil Blackwell.

Eagleton, T. (2003). After Theory, London: Allen Lane.

Foucault, M. (1979). 'What Is an Author?' in Textual Strategies: Perspectives in Post-Structuralist Criticism, ed. Josué V. Harari. London: Methuen.

Foucault, M. (1973). The Order of Things: An Archaeology of the Human Sciences. New York: Vintage.

Fowler, R. (1986). Linguistic Criticism. Oxford: Oxford University Press.

Freud, S., \& Strachey, J. (1985). Psychopathic Characters on the Stage. Pelican Freud LIbrary, 14.

Freud, S., \& Strachey, J. (1986). The Resistances to Psychoanalysis. Pelican Freud LIbrary, 15.

Freud, S., \& Strachey, J. (1986). Psychoanalysis. Pelican Freud LIbrary, 15.

Freud, S., Strachey, J., Richards, A., Dickson, A., \& Breuer, J. (1990). The Penguin Freud Library. London: Penguin Books.

Groden, M. and Martin K., eds. (1994). The Johns Hopkins Guide to Literary Theory and Criticism. Baltimore: Johns Hopkins University Press.

Dahms, H. (2008). Current Perspectives in Social Theory. Current Perspectives in Social Theory, 25, 0278-1204.

Retrieved May 6, 2015.

Horkheimer, M. (1972).Critical Theory: Selected Essays Continuum International Publishing Group.

—, 1982. Critical Theory, New York: Seabury Press.

Ellis, John M.(1989). Against Deconstruction. New Jersey. Princeton University Press.

Lemon Lee T. and Reis, Marion J. Eds. (1965). Russian Formalist Criticism: Four Essays. Lincoln, NE: University of Nebraska Press.

Lentricchia, F. (1980). After the New Criticism. Chicago: University of Chicago Press.

Lukács, G.(1971). The Theory of the Novel.1920. Trans. Anna Bostock. Cambridge, MA: M.I.T. Press.

Macey, D. (2000). The Penguin Dictionary of Critical Theory. London: Penguin.

Macherey, P. (1978). A Theory of Literary Production, trans. Geoffrey Wall. London: Routledge and Kegan Paul.

Makaryk, Irena R., ed. (1993). Encyclopaedia of Contemporary Literary Theory: Approaches, Scholars, Terms.

Toronto: University of Toronto Press.

Mitchell W.J. T., (1985). Against Theory, University of Chicago Press Ltd. London.

Mulhern, Francis, ed. 1992. Contemporary Marxist Literary Criticism. London: Longman.

Raymond G. (1981). The Idea of a Critical Theory. Habermas and the Frankfurt School. Cambridge University Press.

Richards, I. A. (1926). Principles of Literary Criticism. New York: Harcourt, Brace, London: Kegan Paul Trench, Trubner.

Rice, P., \& Waugh, P. (1992). Modern literary theory: A reader. London: Edward Arnold.

Richter, David H. Ed. (1998). The Critical Tradition: Classic Texts and Contemporary Trends. 2nd Ed. Bedford Books: Boston.

Rivkin, Julie and Ryan, Michael.Eds. (1998). Literary Theory: An Anthology. Malden, Massachusetts: Blackwell.

Robert, W. W. (2003). Adorno on Popular Culture, New York: Routledge

Robert, C. S (1983).In the Spirit of Hegel: A Study of G. W. F. Hegel's Phenomenology of Spirit.New York, Oxford University Press.

Rolleston J. (2009). Theodor W. Adorno: An Introduction: Gerhard Schweppenhäuse, trans.: Duke University Press

Showalter, Elaine. Ed. (1986). The New Feminist Criticism: Essays on Women, Literature, and Theory. London: Virago. 
Sim, S. (1995).The A-Z Guide to Modern Literary and Cultural Theorists. Hemel Hempstead: Prentice Hall/Harvester Wheatsheaf.

Tucker, R. C., Marx, K., \& Engels, F. (1978). The Marx-Engels reader. New York: Norton.

Tyson, Lois. (2011). Using Critical Theory. New York: Routledge.

Veeser, H. Aram, ed. (1994). The New Historicism Reader. New York: Routledge

Wellek, R. and Warren, A. (1956). Theory of Literature. New York: Harcourt Brace. Edinburgh: Edinburgh University Press.

Wellek, R. (1963). Literary Theory, Criticism, and History in Concepts of Criticism. New Haven: Yale University Press.

Wolfreys, J., ed. (2002). The Edinburgh Encyclopaedia of Modern Criticism and Theory. Edinburgh: Edinburgh University Press.

Wright, E., ed. (1992). Feminism and Psychoanalysis: A Critical Dictionary. Oxford and Cambridge, Mass.: Basil Blackwell.

Young, R. (1981). Untying the text: A post-structuralist reader. Boston: Routledge \& Kegan Paul. 